\title{
Histopathological Examination of Uterine Tumors and Endometrial Hyperplasias Colonized by Streptococcus agalactiae and Antibiotic Susceptibility of the Isolated Streptococcus agalactiae
}

\author{
Mohammed K. Al- \\ Wiswasy
}

Department of

Pathology

Faculty of Medicine

University of Basrah

\author{
Hadeel T. Al- \\ Hadithi
}

Department of

Biology

College of Science

University of Basrah

Iraq

E-mail: hadeelalhadithi@yahoo.com

Faculty of

Pharmacy
Basrah Maternity

and Child Hospital
University of Basrah

(Received 24/4/2011; Accepted 20/7/2011)

\begin{abstract}
Streptococcus agalactiae was isolated from six leiomyomas of the uterus and two endometrial hyperplasia cases collected from women aged 35 to 80 years, underwent Total Abdominal Hysterectomy (TAH) in Basrah Maternity and Child Hospital due to continuous vaginal bleeding not responding to medical treatment. Sections of leiomyomas stained with haematoxylin and eosin illustrate proliferating smooth muscles fibers with intervening fibrous tissue. Sections from endometrial hyperplasia stained with modified Gram stain demonstrated $S$. agalactiae as diplococci or as aggregates.

Resistance of $S$. agalactiae isolated from the above eight cases, against 14 antibiotics was determined. Results clarified that all isolates (100\%) are resistant to 10 antibiotics: tetracyclin, erythromycin, cefotaxine, ampicillin, chloramphenicol, penicillin, cloxacillin, cephalothin, gentamycin and tobramycin. Most isolates demonstrated susceptibility to amoxicillin $(62.5 \%)$ which makes it the drug of choice against S. agalactiae. Four isolates of $S$. agalactiae $(50 \%)$ were resistant to vancomycin, which raises a threat of vancomycin resistance genes being transferred to other gram-positive species found in the vaginal and rectal sites.
\end{abstract}




\section{الفهص النسب لحالتمن أورلم الرهم وفط نموبلنة الرهم الثي عزلت منها الجرثومة Streptococcus agalactiae}

\section{الملغص}

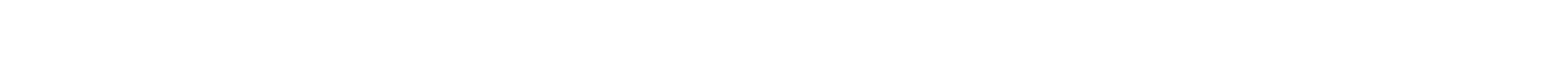

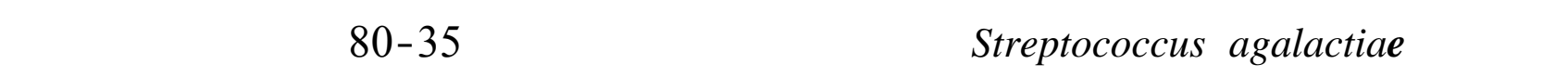

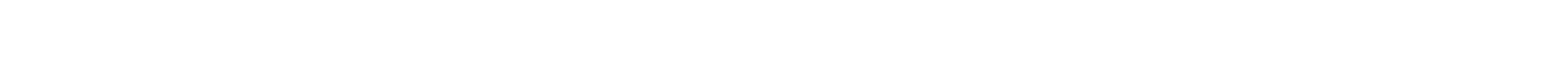
مع العلاج الطبي. أوضحت مقطع نسبج الورم الرحمي المصبغة بالهيماتوكسلين والإيوسين العضلات الملساء المتكاثرة

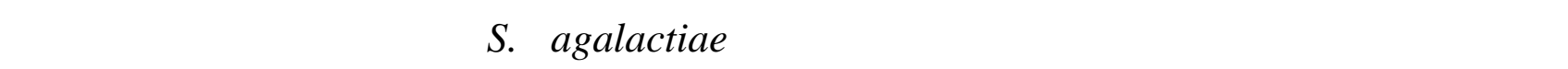

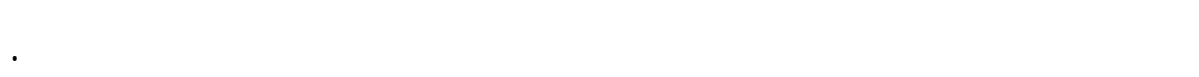

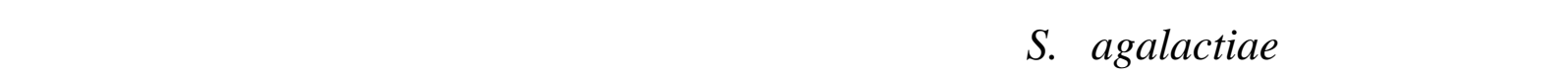

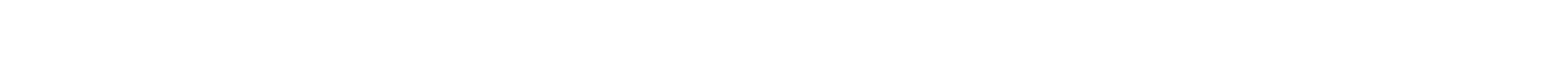

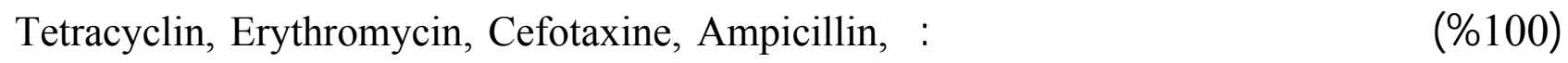
كلت Chloramphenicol, Penicillin, Cloxacillin, Cephalothin, Gentamycin and Tobramycin.

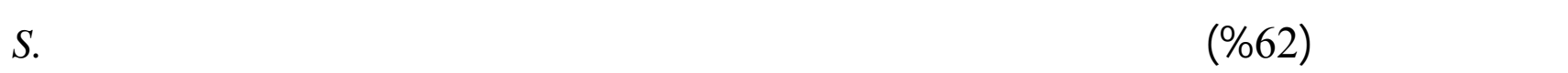

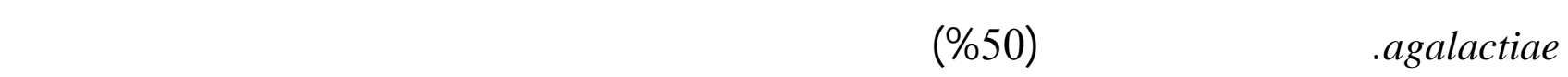

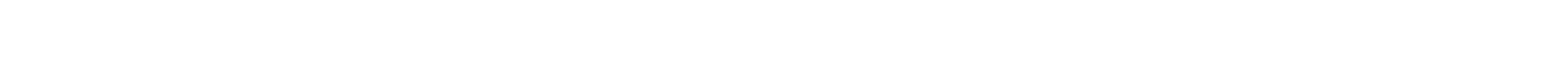
كالمهل والمسققم.

\section{INTRODUCTION}

Group B streptococci (GBS), or Streptococcus agalactiae, is a component of the normal flora, colonizing the respiratory, gastrointestinal, and urogenital tracts of humans. Since the 1970s, S. agalactiae has emerged as an important human pathogen and an increasingly important cause of invasive infections in immunocompromised adults and the elderly (Baker, 2000; Edwards and Baker, 2005). Vertical transmission of S. agalactiae is associated with increased morbidity and mortality in neonates (Gotoff, 2002). Currently, $S$. agalactiae is the leading cause of bacterial sepsis, pneumonia, and meningitis in neonates in the United States, Europe and Asia (Gibbs et al., 2004; Puopolo and Madoff, 2007).

More cases of vaginal GBS colonization were reported in women with gynecological inflammatory conditions, with a significant increase in women with vaginitis and cervicitis (Zhu et al., 1996), cervical cancers (Mikamo et al., 1993) and malodorous and non malodorous gynecologic cancers (VON Gruenigen et al., 2000). Moreover, Genta et al., (2001) reported a case of a diabetic postmenopausal woman with a giant pyomyoma 
simulating an ovarian cancer associated with $S$. agalactiae endocarditis and deep venous thrombosis of the right external iliac and femoral veins.

Adherence of GBS and their invasion into variety of tissue-specific epithelial and endothelial cells host tissue is mediated through a complex series of events which has been confirmed in vitro and in vivo (Mikamo et al., 2004; Martins et al., 2007; Al-Hadithi et al., 2009). Followed by colonization leading to the true depiction of pathogenesis of GBS infection (Soriani et al., 2006).

Penicillins including penicillin $G$ are the drugs of choice for intrapartum antibiotic prophylaxis and also for the treatment of GBS infections (CDC, 2002). For severely penicillin-allergic mothers, the alternative treatment is either erythromycin or clindamycin (Apgar et al., 2005). However, increased antimicrobial use against S. agalactiae isolates has led to the emergence of antimicrobial resistance (Uh et al., 2001; Culebras et al.,2002). Kimura et al., (2008) characterized and identified the first strains of GBS with reduced penicillin susceptibility (PRGBS) in Japan. Likewise, increased rates of erythromycin and clindamycin resistance among GBS has been reported by De Azavedo et al., (2001); Miller et al., (2004), Desjardins et al., (2004); and Zeng et al., (2006). Additionally, women with a complicated pregnancy were found twice as often colonized with GBS strains resistant to macrolides and clindamycin (Strus et al., 2009).

Hence, the present study has focused on examination of tissues of uterine tumors and endometrial hyperplasia colonized by Streptococcus agalactiae and to describe antibiotic susceptibility profile of these isolates.

\section{MATERIALS AND METHODS}

Forty two uterine samples were collected from women age ranged (35 to 80 years), underwent Total Abdominal Hysterectomy (TAH) in Basrah Maternity and Child Hospital due to continuous vaginal bleeding not responding to medical and hormonal treatment. These included: 21 uterine tumors and 21 endometrial hyperplasia.

S. agalactiae was identified in six uterine tumors and two cases of endometrial hyperplasia as Gram positive cocci, negative for catalase, positive for CAMP test, capable of growing in $6.5 \% \mathrm{NaCl}$ but not $40 \%$ bile salts, hydrolyzing arginin and gelatin and were resistant to bacitracin (Facklam and Washington,1991; Collee et al.,1996; Kilian, 1998). Isolates were maintained in Todd Hewitt broth and tryptose blood agar. For testing, the isolates were grown on trypticase soy agar supplemented with $5 \%$ sheep blood at $37^{\circ} \mathrm{C}$ for 18 to $24 \mathrm{hrs}$.

Virulence factors of isolates were confirmed by Al-Hadithi, et al., (2009) including demonstrating existence of the capsule and its intensity using Congo red medium (Freeman, 1979), appearance of turbidity (growth) in Todd Hewitt Glucose Broth (THGB ) containing $4 \mathrm{mg} / \mathrm{ml}$ of purified Tetracycline ( Moffat et al.,1986) which reveals presence of Sialic acid (Nagano et al.,1989) that confers resistance to tetracycline, production of orange to red pigment when colonies were inoculated onto THGB (Gupta and Briski, 2004), blood haemolysis (Collee et al., 1996) and In Vitro adherence capability (Biofilm formation) which was detected by the method of Christensen, (1985). 


\section{Antibiotic Susceptibility Test}

Antibiotic susceptibility of eight $S$. agalactiae isolated from six uterine tumors and two endometrial hyperplasia cases (Al-Hadithi et al., 2009), before processing for histological studies (i.e. before fixing tissues in formalin), was investigated by disc plate method (Mason

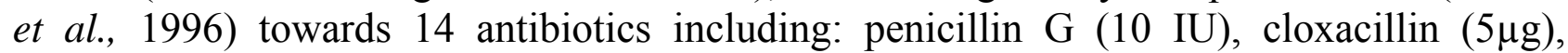
tetracycline $(30 \mu \mathrm{g})$, erythromycin $(15 \mu \mathrm{g})$, ampicillin $(10 \mu \mathrm{g})$, amoxicillin $(30 \mu \mathrm{g})$ trimetheprim $(25 \mu \mathrm{g})$, cefotaxin $(30 \mu \mathrm{g})$, ciprofloxacin $(5 \mu \mathrm{g})$ vancomycin $(30 \mu \mathrm{g})$ and chloramphenicol $(30 \mu \mathrm{g})$ supplied by Oxoid/UK; and gentamycin $(10 \mu \mathrm{g})$ tobramycin $(30 \mu \mathrm{g})$, and cephatollin $(30 \mu \mathrm{g})$ supplied by Al-Razi company/Iraq. Discs were placed on Muller Hinton agar plates supplemented with 5\% blood; two plates for each isolate. Replicate plates were seeded with isolates grown overnight in Todd Hewitt broth and were incubated at $37^{\circ} \mathrm{C}$ for $24 \mathrm{hrs}$. Zones of inhibition were measured by $\mathrm{mm}$ and assessed against standard tables (Harley and Prescott, 1996).

\section{Histopathologic Studies}

Histopathological examination was performed on formalin-fixed, paraffin-embedded tissues of the uterine tumors and endometrial hyperplasia, processed according to Luna (1960) and stained with haematoxylin-eosin stain.

For the detection of S. agalactiae isolates in the tissues; additional sections were prepared and stained by modified Gram's method (McKay, 1970).

\section{RESULTS \\ Histopathological examination of uterine tumors and endometrial hyperplasia harboring S. agalactiae}

(Fig. 1) shows section of a leiomyoma of the uterus. The tumor consists of broad bundles of mature smooth muscle cells that run at various angles, with variable amount of fibrous tissues between the bundles. A section from endometrial hyperplasia stained with modified Gram stain (Fig. 2) demonstrates S. agalactiae as diplococci or aggregates. No acute or chronic inflammatory cell infiltration or reactions were found in both cases of the leiomyomas and the endometrial hyperplasia from which GBS were isolated. 
Fig . 1: Section of leiomyoma of the uterus H.E(X704).
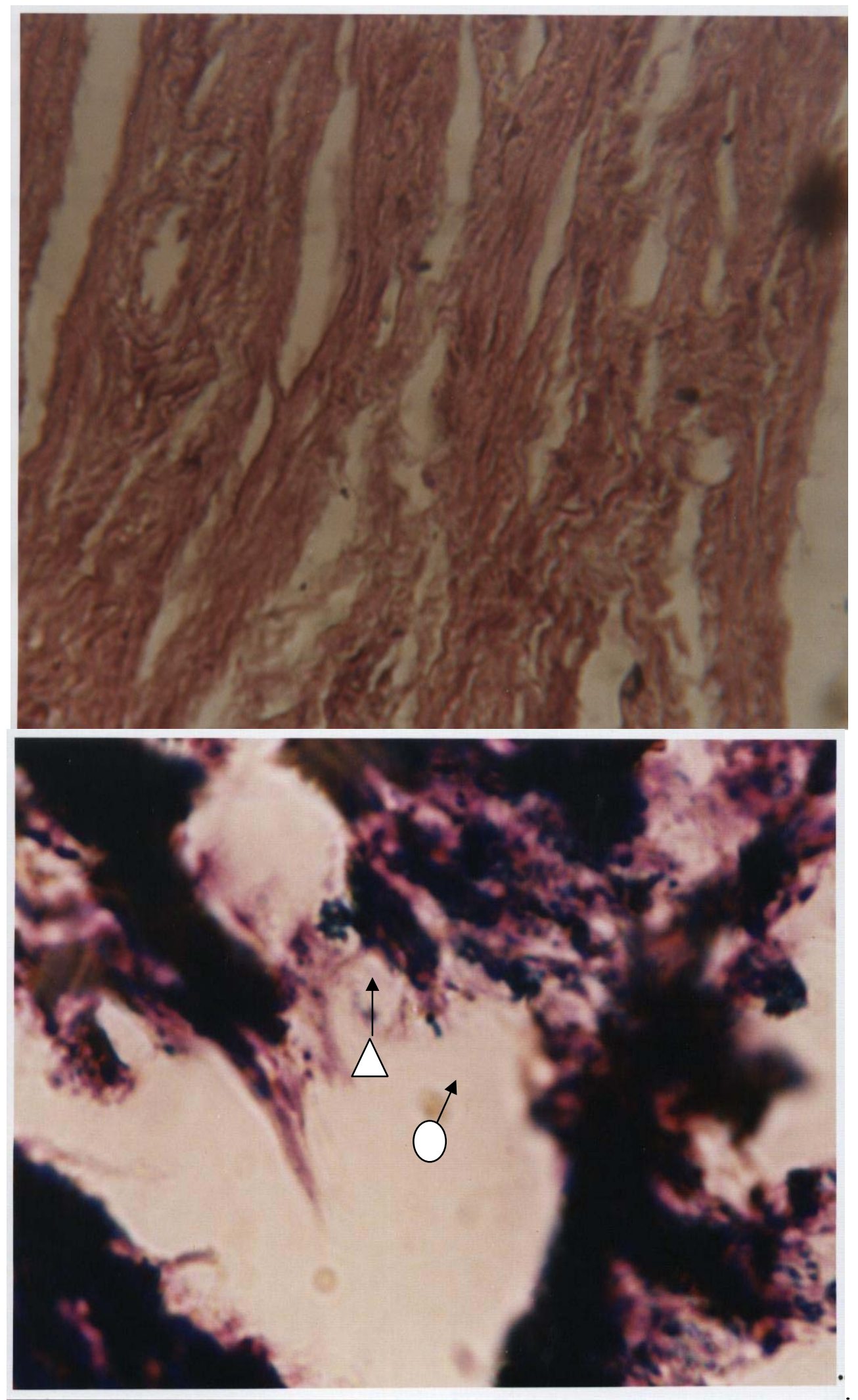

Fig. 2: Modified Gram staining of endomatrial hyperplasia (X-1720) showing Streptococcus agalactiae cells as aggregatesa $(\triangle)$ and diplococci $(O)$ 


\section{Susceptibility of $S$. agalactiae to antibiotics:}

Table (1) illustrates that the eight isolates of $S$. agalactiae under study were resistant to 10 out of 14 antibiotics examined (100\%); Similar percentage $(50 \%)$ of vancomycin resistance was detected between isolates from leiomyoma $(\mathrm{Ca}$ and $\mathrm{Ca} 3)$ and endometrial hyperplasia (Co1).

Only one GBS isolated from a leiomyoma case was susceptible to ciprofloxacin $(12.5$ $\%)$. Most isolates demonstrated susceptibility to amoxicillin $(62.5 \%)$ which makes it the drug of choice against $S$. agalactiae.

\section{DISCUSSION}

Group B Streptococcus commonly colonizes healthy adults without symptoms, yet under certain circumstances displays the ability to invade host tissues, evade immune detection and cause serious invasive disease (Maisey et al., 2008).

Uterine leiomyoma is a benign neoplasm of uterine smooth muscle. It is the commonest tumor in females, being found in $30-50 \%$ of women during their reproductive life. It is generally arises between $20-40$ yrs of age, and tends to stop growing actively after the menopause. Endometrial hyperplasia is an increase in the number of the endometrial glands and their surrounding stromal cells which results eventually in thickening of the endometrium, usually caused by excessive, unopposed action of the estrogens (Colgan et al., 1993; Montag and Kumar, 2007).

Although scarce information is available on bacteriology of pelvic tumors, Mikamo, et al., (2004) indicated that some carcinogens products such as N-nitro compounds, n-butyric acid and n-valeric acid of Enterobacteriaceae, Streptococcus agalactiae and anaerobic bacteria , mainly detected in uterine endometrial cancer might contribute to the initiation of endometrial carcinogenesis, during the critical steps leading to GBS dissemination in the host (Pezzicoli et al., 2008) and biofilm formation (Al- Hadithi et al., 2009). Additionally, Soriani et al., (2006) verified the importance of colonization of the colon and vagina in the pathogenesis of GBS infection with a significant increase in women with gynecologic inflammatory conditions (Zhu et al., 1996). Importantly, infection of placental cells can promote ascending in utero infection, whereas invasion of pulmonary epithelium and endothelium promote systemic dissemination (Maisey and Doran 2008). Moreover, Strus et al., (2009) reported that neonates born from colonized mothers with a complicated pregnancy were more often colonized with GBS than those from the mothers with a normal pregnancy (35\% versus $26.7 \%$ ).

Even so, microbial etiology of female reproductive tract tumors remains unverified and yet, the question of whether GBS alone causes a cancer is not answered ; however, GBS may be an important cofactor, though not the direct.

A greater concern about antimicrobial resistance associated with GBS is whether increased use of antimicrobial prophylaxis in obstetric care for GBS prevention (CDC, 2002) will lead to the emergence of antimicrobial resistance among other perinatal pathogens.

Although the existence of $\beta$-lactam-insusceptible strains of GBS had not been confirmed until the study of Kimura et al., (2008) who identified the first strains of GBS with reduced penicillin susceptibility (PRGBS) in Japan but that study contained clinical isolates stocked from 1995 to 1998 . Hence, they consider that PRGBS have indeed existed since the 1990s. Hence, the establishment of "resistance" criteria for GBS and the 
development of a feasible and reliable method for screening for reduced penicillin susceptibility in GBS are necessitated (Kimura et al., 2008).

Although the results of phylogenetic comparative analysis carried out by Nagano et al., (2008) implied the absence of epidemic penicillin-insusceptible strains, the present study (despite the use of only few isolates) demonstrates resistance of all GBS isolates (100\%) to penicillin (Table 1).

Table 1: Resistance of S. agalactiae isolates against 14 antibiotics.

\begin{tabular}{|c|c|c|c|c|c|c|c|c|c|c|c|c|c|c|}
\hline Isolates & Tob & Gen & Ceph & Van & Clox & Pen & Trim & Cipr & Amp & Cephx & Amo & Chl & Ery & Tet \\
\hline $\mathrm{Ca}_{1}$ & $\mathrm{R}$ & $\mathrm{R}$ & $\mathrm{R}$ & $\mathrm{S}$ & $\mathrm{R}$ & $\mathrm{R}$ & $\mathrm{R}$ & $\mathrm{R}$ & $\mathrm{R}$ & $\mathrm{R}$ & $\mathrm{R}$ & $\mathrm{R}$ & $\mathrm{R}$ & $\mathrm{R}$ \\
\hline $\mathrm{Ca}_{2}$ & $\mathrm{R}$ & $\mathrm{R}$ & $\mathrm{R}$ & $\mathrm{R}$ & $\mathrm{R}$ & $\mathrm{R}$ & $\mathrm{R}$ & $\mathrm{R}$ & $\mathrm{R}$ & $\mathrm{R}$ & $\mathrm{R}$ & $\mathrm{R}$ & $\mathrm{R}$ & $\mathrm{R}$ \\
\hline $\mathrm{Ca}_{3}$ & $\mathrm{R}$ & $\mathrm{R}$ & $\mathrm{R}$ & $\mathrm{S}$ & $\mathrm{R}$ & $\mathrm{R}$ & $\mathrm{R}$ & $\mathrm{R}$ & $\mathrm{R}$ & $\mathrm{R}$ & $\mathrm{S}$ & $\mathrm{R}$ & $\mathrm{R}$ & $\mathrm{R}$ \\
\hline $\mathrm{Ca}_{4}$ & $\mathrm{R}$ & $\mathrm{R}$ & $\mathrm{R}$ & $\mathrm{S}$ & $\mathrm{R}$ & $\mathrm{R}$ & $\mathrm{S}$ & $\mathrm{R}$ & $\mathrm{R}$ & $\mathrm{R}$ & $\mathrm{S}$ & $\mathrm{R}$ & $\mathrm{R}$ & $\mathrm{R}$ \\
\hline $\mathrm{Ca}_{5}$ & $\mathrm{R}$ & $\mathrm{R}$ & $\mathrm{R}$ & $\mathrm{R}$ & $\mathrm{R}$ & $\mathrm{R}$ & $\mathrm{S}$ & $\mathrm{S}$ & $\mathrm{R}$ & $\mathrm{R}$ & $\mathrm{S}$ & $\mathrm{R}$ & $\mathrm{R}$ & $\mathrm{R}$ \\
\hline $\mathrm{Ca}_{6}$ & $\mathrm{R}$ & $\mathrm{R}$ & $\mathrm{R}$ & $\mathrm{R}$ & $\mathrm{R}$ & $\mathrm{R}$ & $\mathrm{R}$ & $\mathrm{R}$ & $\mathrm{R}$ & $\mathrm{R}$ & $\mathrm{R}$ & $\mathrm{R}$ & $\mathrm{R}$ & $\mathrm{R}$ \\
\hline $\mathrm{Co}_{1}$ & $\mathrm{R}$ & $\mathrm{R}$ & $\mathrm{R}$ & $\mathrm{S}$ & $\mathrm{R}$ & $\mathrm{R}$ & $\mathrm{R}$ & $\mathrm{R}$ & $\mathrm{R}$ & $\mathrm{R}$ & $\mathrm{S}$ & $\mathrm{R}$ & $\mathrm{R}$ & $\mathrm{R}$ \\
\hline $\mathrm{Co}_{2}$ & $\mathrm{R}$ & $\mathrm{R}$ & $\mathrm{R}$ & $\mathrm{R}$ & $\mathrm{R}$ & $\mathrm{R}$ & $\mathrm{R}$ & $\mathrm{R}$ & $\mathrm{R}$ & $\mathrm{R}$ & $\mathrm{S}$ & $\mathrm{R}$ & $\mathrm{R}$ & $\mathrm{R}$ \\
\hline$\%$ & 100 & 100 & 100 & 50 & 100 & 100 & 75 & 87.5 & 100 & 100 & 37.5 & 100 & 100 & 100 \\
\hline
\end{tabular}

Tob: Tobramycin $(30 \mu \mathrm{g})$, Gen: Gentamycin $(10 \mu \mathrm{g})$, Ceph: Cephalothin $(30 \mu \mathrm{g})$, Van: Vancomycin $(30 \mu \mathrm{g})$, Clox:

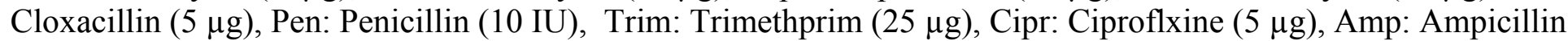
$(10 \mu \mathrm{g})$, Cephx: Cfotoxin $(30 \mu \mathrm{g})$, Amo: Amoxicillin $(30 \mu \mathrm{g})$, Chl: Chroramphenicol $(30 \mu \mathrm{g})$, Ery: Erythromycin $(15 \mu \mathrm{g})$, Tet: Tetracycline $(30 \mu \mathrm{g})$.

In some cases, where In vitro susceptibility data may not be available for prenatal isolates or in cases demonstrating severe penicillin allergies and antibiotic-resistant organisms, the alternative treatment is either erythromycin or clindamycin (Apgar et al., 2005). Both antibiotics, and in a similar way chloramphenicol, exert their bacteriostatic effect by interfering with bacterial protein synthesis through binding preferentially to the 50S subunit of the bacterial ribosome (Brooks et al., 2004). Again, the eight isolates examined in the present study were resistant (100\%) to erythtromycin and chloramphenicol, in addition to another eight antibiotics (Table 1). Increasing resistance of GBS isolates to erythromycin and clindamycin was previously documented by Betriu, (2003) and Manning, et al., (2003). Borchardt et al., (2006) found that clindamycin and erythromycin resistance rates were high among isolates colonizing non pregnant college students and invasive GBS isolates. Zeng et al., (2006) identified resistance to tetracycline, erythromycin, clindamycin and indicated that phenotypic resistance to erythromycin was significantly more common in Asian than in Australasian isolates.

As resistance of $S$. agalactiae isolates against more antibiotics increases, the use of vancomycin will also increase since it has been recommended for prophylaxis of perinatal $S$. agalactiae infection (Miller et al., 2004). On the other hand, higher incidence of Enterococcus was reported to be associated with cefazolin (Newton and Wallace, 1998) and cephalosporin (Hillier et al., 1990) prophylaxis, hence empirical therapy with vancomycin will not be effective; as increased use of vancomycin could precipitate an increase in 
vancomycin resistant enterococci (VRE) in this population raising the possibility for VREassociated postpartum infections. Besides, vancomycin resistance gene in this population might be transferred to other gram-positive species found in the vaginal and rectal sites (Chang et al., 2003 ; Miller et al., 2004).

\section{REFERENCES}

Al-Hadithi, H.T.; Al- Shaheen, H.; Omar, K. E. (2009). Isolation of Streptococcus agalactiae from uterine tumors and endometrial hyperplasia. A study on virulence. BJS. 15(1), 53-60.

Apgar, B. S.; Greenberg, G.; Yen, G. (2005). Prevention of group B streptococcal disease in the newborn. Am. Fam. Physician 71, 903-910.

Baker, C. J.( 2000). "Group B Streptococcal Infections,. In D. L. Stevens and E. L. Kaplan (ed.), Streptococcal Infections". Clinical aspects, microbiology, and molecular pathogenesis. Oxford University Press, Oxford, England. pp. 222-237.

Betriu, C.; Culebras, E.; Gomez M.; Rodriguez-Avial, I.; Sanchez, B. A .; Agreda, M. C.; Picazo J. J. (2003). Erythromycin and clindamycin resistance and telithromycin susceptibility in Streptococcus agalactiae. Antimicrob. Agents Chemother. 47,1112-1114.

Borchardt, S. M.; DeBusscher, J. H.; Tallman, P. A.; Manning, S. D.; Marrs, C. F.; Foxman, B. (2006). Frequency of antimicrobial resistance among invasive and colonizing Group B Streptococcal isolates. BMC Infectious Diseases. 6, 57.

Brooks, C.F.; J. S. Butel; S.A. Morse. (2004). "Jawetz, Melnick and Adelbergs". Medical Microbiology. 23 (ed.). The McGraw-Hill Companies. pp.743-745.

Centers for Disease Control and Prevention (CDC). (2002). Prevention of perinatal group B streptococcal disease. Morb. Mortal. Wkly. Rep. 51, 1-28.

Chang, S.; Sievert, D. M.; Hageman, J. C.; Boulton, M. L.; Tenover, F. C.; Downes, F. P.; Shah, S.; Rudrik, J. T.; Pupp, G. R.; Brown, W. J.; Cardo, D.; Fridkin, S. K. (2003). Infection with vancomycin-resistant Staphylococcus aureus containing the vanA resistance gene. N. Engl. J. Med. 348, 1342-1347.

Christensen, G.D. ; Simpson, W. A. ; Younger, J. I. ; Baddour, I.M. ; Barret, F.F. ; Melton, D.M.; Beachy, E.H. (1985). Adherence of coagulase negative Staphylococci to plastic culture paltes. A quantitative model for the adherence of Staphylococci to medical devices. J. Clin. Microbiol. 22, 996-1006.

Colgan, T.J.; Pendergast, S. and LeBlanc, M. (1993). The histopathology of uterine leiomyoma following treatment with gonadotropin releasing hormone analogues. Hum. Pathol. 24: 1073-1077.

Collee, J.G.; Fraser, A.g.; Marmion, B.P.; Simmon, A. (1996). "Mackie and McCartney". Practical Medical Microbiology. Publisher 4th edn. pp. 270-273.

Culebras, E.; Rodriguez-Avial, I.; Betriu, C.; Redondo, M.; Picazo, J.J. (2002). Macrolide and tetracycline resistance and molecular relationships of clinical strains of Streptococcus agalactiae. Antimicrob. Agents Chemother. 46,1574-1576.

De Azavedo, J. C. S.; Mcgavin, M. C.; Duncan, D.; Low, E.; McGeer, A. (2001). Prevalence and mechanisms of macrolide resistance in invasive and noninvasive group B Streptococcus isolates from Ontario, Canada. Antimicrob. Agents Chemother. 45, 3504-3508. 
Desjardins, M.; Delgaty, K. L.; Ramotar, K.; Seetaram, C.; Toye, B. (2004). Prevalence and mechanisms of erythromycin resistance in Group A and Group B Streptococcus: Implications for reporting susceptibility results. J. Clin. Microbiol. 42 (12), 56205623.

Edwards, M. S.; Baker, C.J. (2005). Group B streptococcal infections in elderly adults. Clin. Infect. Dis. 41, 839-847.

Facklam, R. R.; Washington II, J. A. (1991). "Streptococcus and Related Catalase-Negative Gram-Positive Cocci", In A. Balows, W. J. Hausler, Jr., K. L. Herrmann, H. D. Isenberg, and H. J. Shadomy (ed.), Manual of clinical microbiology, 5th edn. American Society for Microbiology, Washington, D.C pp. 238-257.

Freeman, B.A.(1979). "Burrows Textbook of Microbiology". 20 th ed. pp. 447-W.b. Saunders Company.

Gupta, C.; L.E. Briski. (2004). Comparision of two culture media and three sampling techniques for sensitive and screening of vaginal colonization by group B streptococci in pregnant women. J. Clin. Micro. 42, 3975-3977.

Genta, P.R.; Dias, M.L.; Janiszewski,T.A.; Carvalho, J.P.; Arai, M.H.; Meireles, L.P. (2001) Streptococcus agalactiae endocarditis and giant pyomyoma simulating ovarian cancer. South Med J. 94(5), 508-11.

Gibbs, R. S.; Schrag, S.; Schuchat, A. (2004). Perinatal infections due to group B stretpococci. Obstet. Gynecol. 104,1062-1076.

Gotoff, S. P. (2002). Group B streptococcal infections. Pediatr. Rev. 23, 381-386.

Harley, J.P.; Prescott, L.M. (1996). "Laboratory Excercises in Microbiology". 3rd edn. Printed in the United States of America. 151p.

Hillier, S.; Watts, D. H.; Lee , M.F.; Eschenbach, D. A.(1990). Etiology and treatment of post- cesarean-section endometritis after cephalosporin prophylaxis. J. Reprod Med, 35,322-8.

Kilian, M. (1998). "Streptococcus and Lactobacillus," In A. Balows and B. I. Duerden (eds.), Topley and Wilson's Microbiology and Microbial Infections, 9th edn. Arnold, London, United Kingdom. pp. 633-667.

Kimura, K. S.; Suzuki,J.; Wachino, H.; Kurokawa, K.; Yamane, N.; Shibata,N.; Nagano, H.; Shibayama, K.K.; Arakawa, Y. (2008). First molecular characterization of group B Streptococci with reduced penicillin susceptibility. Antimicrob. Agents Chemother. 52(8), 2890-2897.

Luna, L.G. ; (1960). "Manual of Histologic Staining Methods of the Armed Forced Institute of Pathology".3rd edn. pp.1-74. McGraw-Hill Book Company, New York. London.

Mason, P.R.; Gwanzura, L.; Latif, A.S.; Ray, S.; Wijgert, J.V.; Katzenstein, D.A.(1996). Antimicrobial susceptibility patterns amongst group B streptococci from women in Harer, Zimbabwe. Inter. J. Antimicro. Agents.7, 29-32.

Maisey, H. C.; Doran, K.S. (2008). Recent advances in understanding the molecular basis of group B Streptococcus virulence. Expert Rev Mol Med. 22(10), 27.

Manning, S. D.; Foxman, B.; Pierson,C.L.; Tallman, P.; Baker, C. J.; Pearlman, M.D. (2003). Correlates of antibiotic-resistant group B Streptococcus isolated from pregnant women. Obstet. Gynecol. 101,74-79.

Martins, E. R.; Pessanha, M.A.; Ramirez, M.; Melo-Cristino, J.; and the Portuguese Group for the Study of Streptococcal Infections. (2007). Analysis of group B streptococcal 
isolates from infants and pregnant women in portugal revealing two lineages with enhanced invasiveness. J. Cl. Microbiol. 45(10),3224-3229.

McKay, G. S. (1970). Gram stain modified to improve colour contrast. J. Clin Pathol. 23(2), 191.

Mikamo, H.; Izumi, K.; Ito, K.; Watanabok, K.; Ueno, K.; Tamaya, T. (1993). Endometerial bacterial flora detected in patients with uterine endometrial cancer. KansenshogakuZashsi. 67, 712-717.

Mikamo, H.; Johri, A. K.; Paoletti, L. C.; Madoff, L. C.; Onderdonk, A.B. (2004). Adherence to, invasion by, and cytokine production in response to serotype VIII Group B Streptococci. Infec. and Immu. 72(8), 4716-4722.

Miller, M. B.; Allen, S. L.; Mangum, M. E.; Doutova, A.; Gilligan, P.H. (2004). Prevalence of vancomycin-resistant Enterococcus in prenatal screening cultures. J. Clin. Microbiol. 42, 855-857.

Moffat, A.C.; Jackson, J.V.; Moss, M. S.; Widdop, B.; Greenfield, E.S. (1986). "Clarkes isolation and identification of pharmaceuticals body fluids and post-mortem". 2ed. The Pharmaceutical Press. London.

Montag, A.; Kumar, V. (2007). "The Female Genital System and Breast". In: Robin"s Basic Pathology. Eds: Kumar, V.; Abbas, A.K. ; Fausto, N. and Mitchel, R.N. Chapter 19. Published by Saunders Elsevier. 724p.

Nagano, N.; Nagano, Y.; Kimura, K.; Tamai, K.; Yanagisawa, H.; Arakawa, Y. (2008). Genetic heterogeneity in pbp genes among clinically isolated group B Streptococci with reduced penicillin susceptibility. Antimicrob. Agents Chemother. 52(12), 4258-4267

Newton, E. R. ; Wallace, P. A. (1998). Effects of prophylactic antibiotics on endometrial flora in women with postcesarean endometritis Obstetrics and Gynecology. 92 (2), 262-268.

Pezzicoli, A.; Santi, I.; Lauer, P.; Rosini, R.; Rinaudo, D.; Grandi, G.; Telford, J. L.; Soriani, M. (2008). Pilus backbone contributes to Group B Streptococcus paracellular translocation through epithelial cells. J. Infec. Dis. 198 (6), 890-898.

Puopolo, K. M.; Madoff, L.C. (2007). Type IV neonatal early-onset group B streptococcal disease in a United States hospital. J. Clin . Microbiol. 45(4), 1360-2

Soriani, M.; Santi, I.; Taddei, A.; Rappuoli, R.; Grandi, G.; Telford, J. L. (2006). Group B Streptococcus crosses human epithelial cells by a paracellular route. J. Infect Dis. 15;193(2), 241-50.

Strus, M.; Pawlik, D.; Brzychczy-Włoch, M.; Gosiewski1, T.; Rytlewski, K.; Lauterbach, R.; Heczko, P. B. (2009). Group B streptococcus colonization of pregnant women and their children observed on obstetric and neonatal wards of the University Hospital in Krakow, Poland J. Med. Microbiol. 58, 228-233.

Uh, Y.; Jang, I. H.; Hwang, G. Y.; Yoon, K. J.; Song, W. (2001). Emerging erythromycin resistance among group B streptococci in Korea. Eur. J. Clin.Microbiol. Infect. Dis. 20, 52-54.

VON Gruenigen, V.; Coleman, R. L.; LI, A. J.; Heard, M.C.; Miller, D.S.; Hemsell, D. L. (2000). Bacteriology and treatment of malodorous lower reproductive tract in gynecologic cancer patients. Obstet. Gynecol. 96, 23-271.

Zeng, X.; Kong, F.; Wang, H.; Darbar, A.; Gilbert, G. L.(2006). Simultaneous detection of nine antibiotic resistance-related genes in Streptococcus agalactiae using multiplex PCR and reverse line blot hybridization assay. Antimicrob. Agents Chemother. 50(1), 204209.

Zhu, Y. Z.; Yang, Y.H.; Zhang, X. L. (1996). Vaginal colonization of group B Streptococcus: a study in 267 cases of factory women. Zhonghua Liu Xing Bing Xue Za Zhi. 17(1),17-9. 